\title{
VZDELÁVACIE POTREBY ZAMESTNANCOV V PRESENIORSKOM VEKU
}

KORICINA, M. Vzdelávacie potreby zamestnancov v preseniorskom veku. Nitra: UKF Nitra, 2020. 104 s. ISBN: 978-80-558-1564-0.

Prečo by spoločnost mala byt zodpovedná len za vzdelávanie detí a nie aj za vzdelávanie dospelých akéhokolvek veku?

Erich Fromm

Celoživotné vzdelávanie, zvyšovanie kompetencií a (re)kvalifikácia, sú klúčovými faktormi adaptability človeka v ére internetu, globalizácie a automatizácie. Vplývajú na schopnost dlhodobo využívat jedinečný individuálny potenciál, rozvíjat talenty, majstrovstvo, realizovat sa a byt adekvátne pripravený na zmeny. Organizácie vzdelávaním zamestnancov získavajú mnohé benefity umožňujúce zlepšovat sa a efektívne inovovat v konkurenčnom neustále sa meniacom prostredí. Edukácia a rozvoj zručností v preseniorskom veku sa často podceňujú a obchádzajú nielen zo strany organizácií, ale i samotných pracovníkov, pričom príprava na aktívnu starobu, tzv. aktívne starnutie, má nesporné prínosy. Vedecká monografia Vzdelávacie potreby zamestnancov $\checkmark$ preseniorskom veku reflektuje práve tieto potreby.

Monotematická publikácia, prehl'adne spracovaná na 104 stranách, je členená na 6 kapitol, ktoré na seba logicky nadväzujú. V teoretickej časti (prvá kapitola) autor oboznamuje čitatel'a s trendmi vzdelávania v 21. storočí, definuje stratégie, výzvy pre systém vzdelávania dospelých, elementy politiky vzdelávania dospelých a jej financovania. Opisuje základné faktory a determinanty s významným vplyvom na vzdelávanie dospelých, kvalitu inštitúcií a lektorov vzdelávania. Poukazuje na oblast' klúčových kompetencií podla európskeho referenčného rámca pre celoživotné vzdelávanie, ktoré sú potrebné k stabilnému uplatneniu sa na trhu práce, pre aktívnu participáciu v spoločnosti, osobné naplnenie a rozvoj človeka. V podkapitole 1.3 sa okrajovo venuje základným aspektom vzdelávania na pracovisku, výhodám (ne) 
formálneho vzdelávania a významu informálneho učenia sa v pracovnom prostredí, potvrdzuje prospešnost' a pozitívne dopady nielen pre zamestnancov a organizáciu, ale i pre celú spoločnost'.

Druhá kapitola obsahuje charakteristiku ciel'ovej skupiny, analyzuje jej osobitosti a vymedzuje jej potreby. Autor opisuje špecifiká edukácie v preseniorskom veku, akcentuje obsah vzdelávania a vol'nočasových aktivít v súlade s individuálnymi cielmi a dôležitost' reflexie so záujmami účastníkov. Kategorizuje príznačné oblasti, ako sú sociálne vztahy, zdravie, potreba kompenzácie nedostatkov a d'alšie. Na základe subjektívnych výpovedí účastníkov autorského výskumu, opisuje pomerne častý jav, odmietania edukácie v preddôchodkovom veku. Čast príslušníkov tejto vekovej skupiny má k d’alšiemu vzdelávaniu ambivalentný vztaha a názor, že si uspokojivo vystačia s doterajšími znalostami a skúsenostami. Podkapitola 2.3 analyzuje klúčové dokumenty a mílniky rámca aktívneho starnutia v kontexte celoživotného vzdelávania na Slovensku a d'alšie relevantné dokumenty, súvisiace s predmetnou oblastou výskumu. Opisuje nástroj na meranie a hodnotenie prístupu nevyužitého l'udského potenciálu starších dospelých - index aktívneho starnutia.

Osobitný dôraz kladie (v tretej kapitole) na prípravu odchodu do dôchodku z časového hladiska a východísk preseniorskej edukácie. Zameriava sa na skúsenosti z existujúcich kurzov a programov u nás i v zahraničí. Analyzuje pojem vekový manažment na úrovni orgánov verejnej správy v SR, stratégie, prvky a klúčové témy, ako sú občianske vzdelávanie, digitálne zručnosti a spracovanie informácií, či participáciu v oblasti komunitného života, ako predpoklad aktívneho starnutia, saturáciu potrieb a záujmov. Identifikuje výzvy vekového manažmentu a uplatňovanie princípov vekového manažmentu v organizačnom prostredí, od výberu až po fázu odchodu do dôchodku. V záverečnej podkapitole uvádza viaceré-príklady dobrej praxe doma i v cudzine, ponúka inšpiráciu a rozšírenie obzoru čitatel'a v danej oblasti prostredníctvom odkazov na webové stránky tak národných, ako aj medzinárodných organizácií a projektov venujúcich sa preseniorskej edukácií.

Štvrtá kapitola je zameraná na analýzu vzdelávacích potrieb a motiváciu zamestnancov v preseniorskom veku. Sú to najmä individuálne motívy a dôvody, ktoré rozhodujú o účasti na vzdelávaní. Výskum sa opiera a zároveň potvrdzuje tvrdenia uvedené v teoretickej časti práce - viac než 80\% opýtaných pocituje potrebu sa vzdelávat pre kvalifikovaný pracovný výkon. Dotazníkový výskum skúmal paletu otázok ako sú napríklad: preferovaná 
forma d'alšieho vzdelávania, predstavy o dôchodku, vnímanie dôležitosti a príprava na dôchodok vo firmách, povedomie respondentov o programoch preseniorskej edukácie, ale aj témy a záujmy, ktoré považujú v súvislosti s odchodom do dôchodku za relevantné a vhodné rozvíjat. Autor vhodne využíva ilustrácie príkladov z praxe, prehl'adne zarad'uje grafy a tabul'ky dopĺñajúce text.

Piata kapitola sumarizuje výskumné zistenia edukačných potrieb cielovej skupiny z rôznych pracovných oblastí a regiónov. Vymedzuje tému, základný súbor, formuluje problém, otázky a hypotézy, stanovuje výskumné metódy.

V aplikačnej časti, v šiestej záverečnej kapitole, autor predstavuje edukačný program s názvom 55 plus, koncipovaný na základe zistených potrieb, preferencií účastníkov výskumu, reflektujúc aktuálne požiadavky trhu práce. V štyroch moduloch, rôznymi učebnými metódami, ako sú prednáška, demonštrácia, skupinová práca, diskusia, praktické cvičenia a úlohy, navrhuje na mieru „šitý“ kurz, zameraný na získanie vybraných kompetencií cez vol'nočasové vzdelávacie aktivity. Účastníkom predstaví koncept aktívneho starnutia, umožní spoznat pozitívne perspektívy, príležitosti, iniciovat aktivitu a pomáhat pri vytváraní nových vztahov v atmosfére sociálnej skupiny. Druhý modul sa zaoberá digitálnym svetom, komunikačnými zručnostami v online prostredí a vyhladávaním edukačných príležitostí. Tretia časț rozširuje prehl'ad a zvyšuje kompetencie účastníkov v oblasti financií a plánovania, obsahuje viaceré praktické cvičenia. Posledná časṫ ponúka pohl'ad na možnosti participácie na komunitnom živote a projektoch rôznych záujmových organizácií. Účastníci vzdelávania identifikujú a analyzujú svoje záujmy a súčasný spôsob trávenia volného času. Navrhnutý program je, samotným zameraním tém a interaktivitou, vhodnou a najmä aktuálnou edukačnou pomôckou pri orientácii preseniorov v tematike aktívneho a zdravého starnutia. Umožňuje sebareflektívne zhodnotit pripravenost' na výzvy a perspektívy spojené s odchodom do dôchodku.

Ako autor uvádza, cielom monografie bolo ponúknut teoreticko-metodologický prienik do problematiky vzdelávacích potrieb 55 a viac ročných zamestnancov. Môžeme konštatovat', že tieto ciele boli naplnené. Prínosom monografie je obsahovo ucelená práca podložená vlastným výskumom. Oceňujem najmä prehl'adné spracovanie rámca aktuálnych politík týkajúcich sa kontinuálneho vzdelávania, porovnanie so zahraničnými edukačnými programami, využitie literárnych zdrojov z novodobých štúdií, zahraničných prameňov a najmä množstvo praktických príkladov, ktoré potvrdzujú, 
že investovanie do vzdelávania je opodstatnené a rentabilné v každom veku. Recenzentmi publikácie sú významní odborníci z oblasti vzdelávania dospelých - prof. PhDr. Beáta Balogová, PhD. a prof. PaedDr. Miroslav Krystoň, CSc. Monografia vhodne dopíňa spektrum knižných titulov z oblasti andragogiky, môže slúžit ako východisko d'alšieho empirického výskumu, ako podporný materiál pre študentov andragogiky, lektorov, manažérov, personalistov, kultúrno-osvetových pracovníkov, ale i ostatným profesionálom v oblasti vzdelávania a tvorby programov vol'ného času dospelých. Publikácia je písaná zrozumitelným jazykom vhodným aj pre oboznámenie sa laickej verejnosti s konceptom aktívneho starnutia a v neposlednom rade pre cielovú skupinu - zamestnancov v preseniorskom veku, ako príležitost' na prehodnotenie pasívneho postoja, zmenu prístupu, hlbšie zamyslenie sa, prevzatie zodpovednosti za prípravu na aktívnu starobu a zároveň obohatenie života kreatívnymi edukačnými aktivitami.

\section{Autorka recenze}

Ing. Slavka Silberg, MBA

Univerzita Konštantína filozofa v Nitre, Pedagogická fakulta, Katedra pedagogiky, Dražovská cesta 4, 94974 Nitra, Slovenská republika email: slavka.silberg@ukf.sk

Přijato: 3. 11. 2020

Link to this article: https://doi.org/10.11118/lifele20211101099 